\title{
BOTANICAL COMPOSITION OF ALPACA (Lama pacos Linn.) DIET IN A CENTRAL MEDITERRANEAN RANGE OF CHILE
}

\author{
G. Castellaro G. ${ }^{1}$, F. Squella N. ${ }^{2}$, F. León C. ${ }^{3}$, and A. Raggi S. ${ }^{4}$
}

\begin{abstract}
A B S T R A C T
The re-introduction of domestic South American camelids (alpacas and llamas) in the central zone of Chile makes it necessary to study their behaviour and adaptability. Since it is fundamental to characterize the camelid's diet, the present work had as an objective the determination of the plant species selected by the alpacas (Lama pacos Linn.) in different phenological stages (vegetative, reproductive and dry season). The study was carried out over three years in a paddock of 2.5 ha of sparse shrubland dominated by Acacia caven (Mol.) Mol. and annual species in the herbaceous stratum, which were continually grazed by five male alpacas. The botanical composition and the forage dry matter available for grazing in the pasture was evaluated. Botanical composition of diets was estimated with the microhistological technique, using dung samples collected directly from the rectum. During the vegetative season, the most consumed plant species were annual and perennial grasses. In the reproductive season, the most important components of the diet were woody plant species, annual grasses and forbs. In the dry season, the diet was composed of a high percentage of woody plant species.
\end{abstract}

Key words: alpaca, annual Mediterranean range, botanical composition, microhistology.

\section{INTRODUCTION}

The alpaca is raised in Chile mainly in the highlands of the Arica and Parinacota Region, developing in a high altitude environment under conditions of climatic extremes. Feeding is based on the use of peatlands (termed "bofedales") and dry land pasture (tussocks grassland or "pajonales" and shrubland range or "tholares"), with the former being more important, which results in great specialization in grazing habits (Castellaro et al., 2004).

Numerous studies are in agreement that the alpaca adapts its consumption to pasture species in accordance to the availability of the same (Bryant and Farfán, 1984; Reiner and Bryant, 1986), which suggests a great capacity to adapt itself to different types of pastures (San Martín and Bryant, 1989). This is an important characteristic for the re-introduction of this camelid to the central dry lands of Chile, given the marked differences observed with regard to the pastures used for this herbivore in the highlands. The high degree of specialization of its diet in highland grasslands (Castellaro et al., 2004), suggests that the alpaca could have a low capacity to adapt to changes in environmental, feeding and management conditions that are implied by its introduction to the dry lands of the central zone. Nevertheless, in preliminary evaluations, this has not been observed, with the animal showing adaptability and maintaining adequate indices of reproduction, growth and productivity (Castellaro et al., 1998), which could be attributed in part to the fact that in the coastal dry lands of the central zone of Chile the characteristics of quality,

\footnotetext{
${ }^{1}$ Universidad de Chile, Facultad de Ciencias Agronómicas, Casilla 1004, Santiago, Chile.

E-mail: gicastel@uchile.cl_*Corresponding author.

${ }^{2}$ Instituto de Investigaciones Agropecuarias, Centro Regional de Investigación Rayentué, Centro Experimental Hidango, Casilla 3, Litueche, Chile. E-mail: fsquella@inia.cl

${ }^{3}$ Bayer S.A., Longitudinal Sur km 92, Los Lirios, Rancagua, Chile.

${ }^{4}$ Universidad de Chile, Facultad de Ciencias Veterinarias y Pecuarias, International Centre for Andean Studies (INCAS), Casilla 2, Correo 15, Santiago, Chile.

Received: 3 January 2007. Accepted: 1 June 2007.
} 
diversity of species and pasture dry matter production differs from what these animals normally graze on in the highlands range.

The establishment of experimental and productive flocks of alpacas in the central and southern zones of Chile presents the need to undertake evaluations of the feeding behavior of this herbivore to understand its adaptability, and in this way quantify the bioeconomic viability of this system. The main objective of this work was to determine the vegetal species selected by the alpaca when they graze in natural grassland of mediterranean climate in its different phenological stages.

\section{MATERIALS AND METHOD}

\section{Area of study}

The study was carried out in 1994, 1995 and 1996, at the Hidango Experimental Center of the Instituto de Investigaciones Agropecuarias (INIA), located in the community of Litueche, Cardenal Caro Province, Libertador General Bernardo O'Higgins Region ( $34^{\circ} 06^{\prime} \mathrm{S} ; 71^{\circ} 47^{\prime} \mathrm{W} ; 296 \mathrm{~m}$.a.s.1.). The climate is of a Mediterranean type, with temperatures that vary on average between a maximum of $24.7^{\circ} \mathrm{C}$ in February and a minimum of $5.4{ }^{\circ} \mathrm{C}$ in June. The frost free period is 365 days. Annually 1,328 degree days and 550 chilling hours are registered. Average annual precipitation is $825 \mathrm{~mm}$, with a water deficit of $1,024.4$ $\mathrm{mm}$ and a dry season of 7 months (Santibáñez and Uribe, 1990). Registered precipitation during the period of the study (1995, 1996 and 1997) was 505, 692 and $522 \mathrm{~mm}$, these years being classified as dry, normal, and dry, respectively.

Soils are of a sedimentary type, deep, with a clay loamy texture and dark brown in color at the surface, and with a clay texture at more depth. They are classified as Typic Palexeralfs (Soil Survey Staff, 1992), with moderate permeability and good drainage. The organic material content is on the order of $3 \%$. The levels of mineral $\mathrm{N}$ and $\mathrm{P}$ are low, the $\mathrm{K}$ content being moderate to high. The $\mathrm{pH}$ is slightly acidic and does not present problems of salinity (Castellaro and Squella, 1995, personal communication). The vegetal formation is an open pseudo-savanna (Ovalle et al., 1990), with an shrub strata dominated by Acacia caven (Mol.) Mol. and Rubus ulmifolius Schott, and a herbaceous strata composed mainly of winter growth terophyta, where annual grasses dominate, in particular the genera Avena, Aira, Bromus, Hordeum,
Lolium and Vulpia and some perennial grasses belonging to the genera Piptochaetium and Nasella. Species of the Asteraceae and Fabaceae families are also common (Castellaro et al., 1994; Ovalle and Squella, 1996).

\section{Design of the study}

The study was carried out on an area of 2.5 ha of cleared brushwood of $A$. caven, on which five adult male alpacas of the Huacaya breed grazed, under continuous grazing system during the 1994-1995, 1995-1996 and 1996-1997 seasons. Evaluations, which will be discussed further on, were carried out in the study.

\section{Pasture botanical composition}

This measurement was made in the pasture in the vegetative, reproductive and dry phenological stages. The vegetative period was defined as being from the emergence of annual species (or the beginning of regrowth of perennial species) until the beginning of the flowering (sprouting) of the same; the reproductive period as being from flowering until the dominant species completed the maturation of their seeds; and the dry period as that between the maturation of seeds and the moment that emergence (annual species) or regrowth (perennial species) begins again. These states were estimated visually, considered as such when at least $50 \%$ of the observed species presents a particular state. Botanical composition of the herbaceous strata was evaluated using the Modified Point-Quadrat Method (Etienne et al., 1979), determining homogenous vegetal elements on the basis of a vegetational mapping developed in a previous study (Castellaro and Squella, 1995, personal communication). In each of these, permanent transects of 4-meter-long were established, the number of which was determined in function of the proportion of each element in relation to the total of the evaluated surface area. The values of the botanical composition obtained in each of the transects and for each vegetational element was summed and averaged, thus obtaining a mean value for all of the evaluated surface area.

\section{Pasture dry matter (DM) availability and accumulation}

This measurement was made in the three aforementioned phenological stages. The availability of pasture DM $\left(\mathrm{kg} \mathrm{ha}^{-1}\right)$ was determined under grazing, and accumulation of total pasture DM of each season $\left(\mathrm{kg} \mathrm{ha}^{-1}\right)$ for which $1.3 \mathrm{~m}^{2}$ exclusion cages were arranged closed to the permanent lines within the 
homogeneous vegetational elements. The number of cages was determined in relation to the proportion of each element. To measure the availability and accumulation of pasture DM, the herbaceous material was cut at ground level and weighed in fresh state; from which a sample of $200 \mathrm{~g}$ was taken and dehydrated in a forced air oven at $70^{\circ} \mathrm{C}$ for $48 \mathrm{~h}$, for the purpose of determining DM percentage.

\section{Botanical composition of diets}

To determine this variable, a microhystological analysis of feces was used (Spark and Malechek, 1968; Holechek et al., 2001). The prepared patterns of the epidermis of the different vegetal species were obtained from fragments of the herborized plants, using the procedures described by Castellaro et al. (2006). With the aim that the analysis of the diet was representative of the botanical composition of the pasture, the samples of feces were collected in the same period that the evaluation of pasture botanical composition was made. The samples of feces were taken directly from the rectum of each animal for 5 consecutive days, preparing a compounded sample for each animal at the end of this period. These samples were dehydrated in a forced air oven at $70{ }^{\circ} \mathrm{C}$ for $48 \mathrm{~h}$ and were ground to $1 \mathrm{~mm}$ particles in a Willey type grinding mill. The samples were subsequently bleached with a solution of sodium hypochlorite and were mounted on microscope slides using glycerin gel with phenol as a means of mounting. Five slides were prepared per compound sample of feces of each animal, in which 100 fields were evaluated with an optical microscope (Ernst Leitz, GMBH, Wetzlar, Germany), with a magnification of 100x. Within each field, the frequency of the species in the diet was determined through the registry of each identifiable fragment of epidermis. Subsequently, the frequency obtained of each species was transformed into density, using the tables proposed by Fracker and Brischle (cited by Spark and Malechek, 1968).

\section{Experimental design and statistical analysis}

The availability of DM and botanical composition of the pasture were analyzed by means of descriptive statistic, developing profiles of these variables over time. The percentages of the main species of the diet were submitted to a variance analysis, under a splitplot experimental design, prior to angular transformation of the data. The year was considered as the main plot and the phenological stage as the subplot (Steel and Torrie, 1988). The measurements made in the months of June and August were considered representative of the vegetative period, those made between September and November representative of the reproductive period and those carried out between January and April representative of the dry period. The Duncan's multiple range test was made to detect significant differences $(\mathrm{P} \leq 0.05)$.

With the objective of globally evaluating the diversity of the botanical composition of the pasture and the diet, the averages of these variables obtained in each evaluation were used to calculate the Shannon's Diversity Index, which is expressed as relative diversity (E) (Cortés et al., 2002; Castellaro et al., 2004). Finally, Ivlev's Electivity Index (IS) was estimated for the main vegetal species consumed, using jointly the averages of botanical composition of the diets and of the pasture (Krebs, 1989; Stuth, 1991). The IS has values between 1.0 and -1.0. The positive, zero and negative values indicate selection, indifference and rejection, respectively. Only herbaceous species were considered in this calculation.

\section{RESULTS AND DISCUSSION}

\section{Botanical composition, dry matter production and pasture availability under grazing}

Annual grasses were the dominant species group (Figure 1), mainly Bromus hordeaceus L. (40.7\%), Lolium rigidum Gaudin (4.4\%) and Hordeum berteroanum E. Desv. ex C. Gay (4.3\%). Herbaceous dicots (forbs) were in second place, and within this group Hypochaeris glabra L. (7\%) and species of the genus Trifolium (6\%) stood out. Among the perennial grasses, Nassella manicata (E.Desv.) Barkworth made an important contribution (15.1\%).

Accumulated DM production of the pasture reached values of 5,326; 4,678 and 3,832 $\mathrm{kg} \mathrm{ha}^{-1}$, in the 19941995, 1995-1996 and 1996-1997 seasons, respectively. The differences observed could be attributed to the pluviometric situation of these years, given that the productivity and growth rhythm of annual grasslands in a Mediterranean climate are determined by the volume and distribution of precipitation (Olivares et al., 1998; Johnston et al., 1998; Olivares et al., 2004; Olivares et al., 2006).

\section{Botanical composition of diets}

The percentage participation in the diet of each group of species (annual and perennial grasses, herbaceous dicots and woody species) varied depending on the 


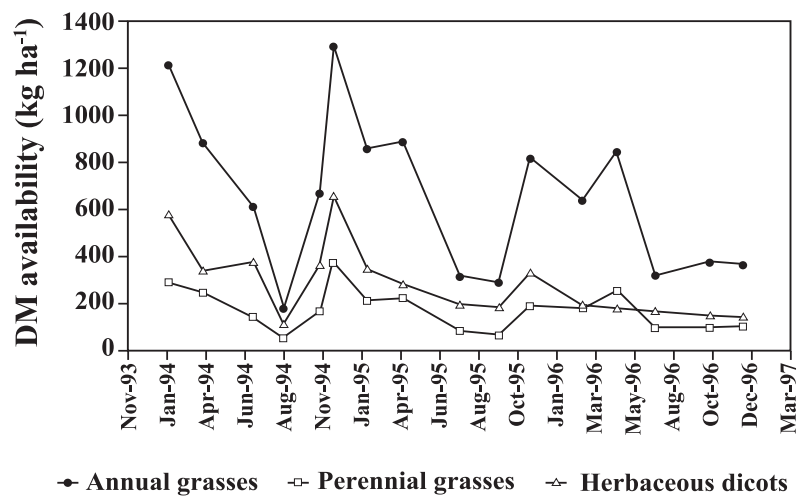

Figure 1. Dry matter availability of different species groups in the grazed pasture. Hidango, Libertador General Bernardo O'Higgins Region, Chile.

phenological stage of the pasture (Figure 2). From the moment in which annual species emerged and perennials regrowth, and although in that moment the pasture offered less availability of DM, the diet of the alpacas was based on the consumption of annual and perennial grasses. Nevertheless, and although they were available, herbaceous dicots were not consumed as much. Woody species, and in particular, A. caven, participated in a lesser proportion in this time, probably due to the scarce foliage observed in the branches of this species during this period. Further on in the season, herbaceous species began to be more available in the pasture, developing reproductive structures and lignifying. This process occurred earlier in the perennial grasses, which was reflected in the reduction of consumption of this last group. In this time, herbaceous dicots species had more relative importance, given that the loss of quality in this species is not as accentuated as in the grasses (George et al., 2001). During this same period, woody species began to increase their participation in the diet.

When the species of the pasture completed their fructification and enter in senescence, period in which the greatest availability of DM is reached, consumption is oriented to woody species, given that in this moment these species have green foliage and are preferred by the animals, probably to satisfy protein and carotene requirements. At the beginning of the new autumn season (March-April), the perennial

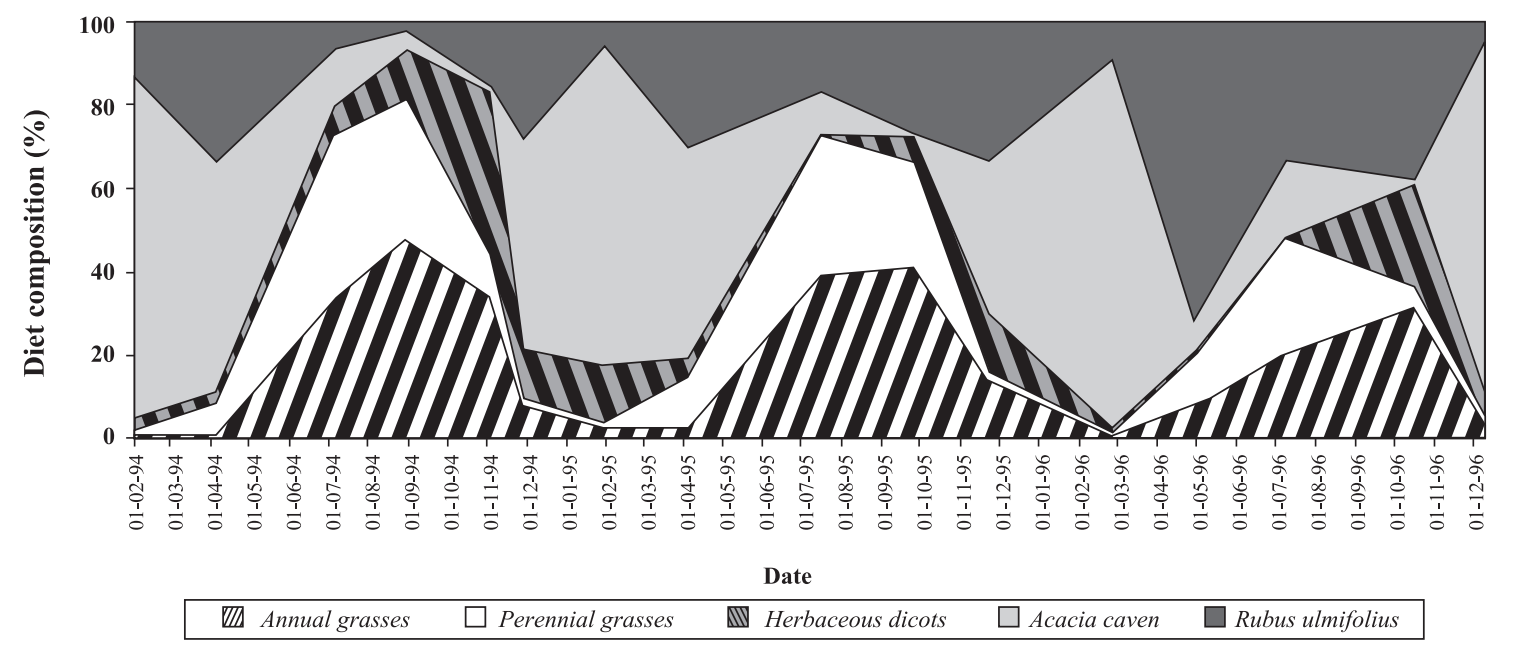

Figure 2. Percentage of different species groups in the alpacas' diet, during experimental period. Hidango, Libertador General Bernardo O'Higgins Region, Chile. 
species of the pasture, N. manicata and Piptochaetium stipoides (Trin. \& Rupr.) Hack. ex Arechav., were the first in developing new foliage and began gradually to appear in the diet. This suggests that the alpacas selected their diet primarily in function of the nutritive quality of the pasture species and secondly in function of availability, with greater consumption of woody species, above all in the summer season when the herbaceous strata are completely dry. This situation is consistent with the behavior observed in sheep in a similar range located in the semiarid dry land of the central zone (Riveros et al., 1978; Soto and Silva, 1984).

The resulting averages of the groupings according to the vegative, reproductive and dry period, and the most important species within each group are presented in Table 1. The difference in the percentage of species in the distinct periods was important, observing high variability even within each period. In the vegetative period, uniformity was observed in the percentages of the diet for each group of species, in the three seasons and among each of the analyzed dates. The consumption of annual and perennial excelled with 35 and $34 \%$, respectively; woody species contributed an average of $26.4 \%$, which is relatively high if the quality of the pasture in this epoch is considered (Table 1). Herbaceous dicots contributed $4.6 \%$, which indicates greater selectivity by the grasses, and as with the other species, in the winter months these species are in the vegetative state and available to the animals.

It was necessary to divide the reproductive period of the pasture into early and late, based on chronological criteria, given that significant differences were observed in the proportion of species between the evaluation dates within this period $(\mathrm{P} \leq 0.05)$. In the early reproductive period, the contribution of the different groups was $35 \%$ for annual grasses, $28 \%$ for woody species, $23 \%$ for herbaceous dicots and $14 \%$ for perennial grasses. Comparing this period to the vegetative, a greater participation of herbaceous dicots and woody species in the diet was observed, which increased in the context of the decline of the perennial grasses, probably due to the greater degree of lignification of these species during this phenological state. In the late reproductive period, woody species contributed with $80 \%$ to the botanical composition of the diet, while the contribution of the herbaceous

Table 1. Alpaca's diet botanical composition (\%) (average \pm SD) according to range phenological stage.

\begin{tabular}{|c|c|c|c|c|c|c|c|}
\hline \multirow[t]{3}{*}{ Group of species } & \multicolumn{7}{|c|}{ Phenological state of the pasture } \\
\hline & \multirow[t]{2}{*}{ Vegetative } & \multicolumn{3}{|c|}{ Reproductive } & \multicolumn{3}{|c|}{ Dry } \\
\hline & & Early & Late & Average & Early & Late & Average \\
\hline \multicolumn{8}{|l|}{ Annual grasses } \\
\hline $\begin{array}{l}\text { Bromus hordeaceus } \\
\text { Hordeum berteroanum } \\
\text { Lolium rigidum } \\
\text { Vulpia bromoides } \\
\text { Subtotal }\end{array}$ & $\begin{aligned} 0.9 & \pm 0.5 \\
8.4 & \pm 3.0 \\
7.8 & \pm 5.2 \\
18.1 & \pm 6.5 \\
35.2 & \pm 11.7\end{aligned}$ & $\begin{array}{r}0.5 \pm 0.5 \\
9.0 \pm 4.6 \\
8.6 \pm 2.6 \\
17.3 \pm 6.7 \\
35.5 \pm 5.0\end{array}$ & $\begin{array}{l}2.0 \pm 1.2 \\
1.4 \pm 1.0 \\
1.8 \pm 1.1 \\
3.3 \pm 2.3 \\
8.5 \pm 5.4\end{array}$ & $\begin{aligned} 1.2 & \pm 1.2 \\
5.2 & \pm 5.1 \\
5.2 & \pm 4.1 \\
10.3 & \pm 8.9 \\
21.9 & \pm 15.5\end{aligned}$ & $\begin{array}{l}0.2 \pm 0.2 \\
0.2 \pm 0.2 \\
0.6 \pm 0.2 \\
0.2 \pm 0.2 \\
1.2 \pm 1.0\end{array}$ & $\begin{array}{c}0.6 \pm 0.3 \\
- \\
1.7 \pm 1.5 \\
1.2 \pm 1.9 \\
3.5 \pm 3.6\end{array}$ & $\begin{array}{l}0.4 \pm 0.3 \\
0.1 \pm 0.2 \\
1.2 \pm 1.1 \\
0.7 \pm 1.3 \\
2.4 \pm 2.7\end{array}$ \\
\hline \multicolumn{8}{|l|}{ Perennial grasses } \\
\hline $\begin{array}{l}\text { Piptochaetium stipoides } \\
\text { Nasella manicata } \\
\text { Subtotal }\end{array}$ & $\begin{array}{l}21.7 \pm 3.3 \\
12.2 \pm 3.2 \\
33.9 \pm 4.9 \\
\end{array}$ & $\begin{aligned} & 7.5 \pm 7.9 \\
& 6.3 \pm 2.5 \\
& 13.8 \pm 10.5 \\
&\end{aligned}$ & $\begin{array}{l}0.9 \pm 0.6 \\
0.9 \pm 0.4 \\
2.2 \pm 0.4\end{array}$ & $\begin{array}{l}4.2 \pm 6.1 \\
3.6 \pm 3.4 \\
7.8 \pm 9.1 \\
\end{array}$ & $\begin{array}{l}0.4 \pm 0.2 \\
0.7 \pm 0.2 \\
1.1 \pm 0.3\end{array}$ & $\begin{array}{r}3.2 \pm 1.0 \\
7.6 \pm 2.1 \\
10.8 \pm 2.8 \\
\end{array}$ & $\begin{array}{l}1.8 \pm 1.7 \\
4.1 \pm 4.0 \\
5.9 \pm 5.6\end{array}$ \\
\hline \multicolumn{8}{|l|}{ Herbaceous dicots } \\
\hline $\begin{array}{l}\text { Hypochaeris glabra } \\
\text { Medicago polymorpha } \\
\text { Subtotal }\end{array}$ & $\begin{array}{c}4.2 \pm 5.3 \\
- \\
4.6 \pm 5.4 \\
\end{array}$ & $\begin{array}{c}23.1 \pm 16.5 \\
- \\
23.1 \pm 16.6 \\
\end{array}$ & $\begin{array}{r}7.4 \pm 3.8 \\
2.9 \pm 0.1 \\
10.3 \pm 3.7 \\
\end{array}$ & $\begin{aligned} & 15.3 \pm 13.7 \\
& 1.5 \pm 1.6 \\
& 16.7 \pm 12.8 \\
&\end{aligned}$ & $\begin{array}{l}0.7 \pm 0.6 \\
5.3 \pm 6.3 \\
6.0 \pm 7.0\end{array}$ & $\begin{array}{l}1.5 \pm 0.9 \\
1.1 \pm 0.9 \\
2.6 \pm 1.78 \\
\end{array}$ & $\begin{array}{l}1.1 \pm 0.8 \\
3.2 \pm 4.7 \\
4.3 \pm 4.9\end{array}$ \\
\hline \multicolumn{8}{|l|}{ Woody species } \\
\hline $\begin{array}{l}\text { Acacia caven } \\
\text { Rubus ulmifolius } \\
\text { Subtotal }\end{array}$ & $\begin{array}{l}11.8 \pm 6.9 \\
14.6 \pm 13.7 \\
26.4 \pm 18.7\end{array}$ & $\begin{array}{c}0.9 \pm 0.4 \\
26.7 \pm 11.1 \\
27.6 \pm 11.3\end{array}$ & $\begin{array}{l}57.2 \pm 24.1 \\
22.1 \pm 15.2 \\
79.3 \pm 9.1\end{array}$ & $\begin{array}{l}29.1 \pm 34.4 \\
24.4 \pm 12.2 \\
53.5 \pm 29.7\end{array}$ & $\begin{array}{r}82.5 \pm 5.8 \\
9.1 \pm 3.6 \\
91.6 \pm 8.2\end{array}$ & $\begin{array}{l}38.1 \pm 26.4 \\
45.0 \pm 23.3 \\
83.1 \pm 5.0\end{array}$ & $\begin{array}{l}60.3 \pm 29.7 \\
27.1 \pm 24.6 \\
87.4 \pm 7.7\end{array}$ \\
\hline
\end{tabular}

- : without information. 
dicots and annual and perennial grasses were 10,8 and $2 \%$, respectively (Table 1 ).

The tendency observed in the late reproductive period continued during the dry period, which was also subdivided into early and late, because of significant differences found among the measurements made during this period $(P \leq 0.05)$. At the beginning of the dry period, $92 \%$ of the species are woody. The contribution of herbaceous dicots was $6 \%$ and annual and perennial grass species did not exceed $2 \%$. In the late dry period, woody species returned to being dominant in the diet (83\%), perennial grasses rose to $11 \%$ and annual grasses and herbaceous dicots contributed 4 and $3 \%$ of the diet, respectively (Table 1 ). The high contribution of woody species observed during the late reproductive and dry periods can be attributed to the nutritional need of the animals to select a diet high in carotene and protein, nutrients that are present in a greater percentage in the forage resources that remain green during these phenological stages.

An analysis within each group of species (Table 2) showed that in the group of annual grasses, and during the vegetative period, the species that contributed more to the diet were Vulpia bromoides (L.) Gray,, B. hordeaceus, $H$. berteroanum and L. rigidum. The contribution of these species differed significantly ( $\mathrm{P}$ $\leq 0.05$ ) among the three seasons studied. In the first year, the participation of this group in the vegetative, reproductive and dry periods was $41.0,21.0$ and $0.7 \%$, respectively $(\mathrm{P} \leq 0.05)$. In the second year it was similar, with $39.5,27.5$ and $2.3 \%$, for the same periods $(\mathrm{P} \leq 0.05)$. However, in the third year of the study, this contribution in the vegetative and reproductive periods was 20 and $17.4 \%$, without significant differences between them $(\mathrm{P}>0.05)$. Nevertheless, in the dry period the percentage of this species was $4.1 \%$, differing significantly from the other two periods ( $\mathrm{P}$ $\leq 0.05$ ). Upon analyzing each of the aforementioned grasses individually, $H$. berteroanum, $L$. rigidum and $B$. hordeaceus did not present significant differences among the periods in the three seasons analyzed $(\mathrm{P}>$ 0.05 ), which reflects a behavior that is repeated year after year. The exception was $V$. bromoides, which participated in greater quantity among the group, especially in the dry and reproductive period (Table 2).

Among the group of perennial grasses, the species $N$. manicata and P. stipoides are notable for presenting the same behavior throughout the year (Table 2), without significant differences among years $(\mathrm{P}>0.05)$.

The percentage participation of the herbaceous dicots was mainly represented by the species Medicago polymorpha L. and $H$. glabra (Table 2). The contribution of these species behaved distinctly in the

Table 2. Contribution to the diet (\%) of main species consumed by alpacas at different phenological stages during the three seasons of the experimental period. Hidango, Libertador General Bernardo O'Higgins Region, Chile.

\begin{tabular}{|c|c|c|c|c|c|c|c|c|c|}
\hline \multirow[t]{4}{*}{ Plant species } & \multicolumn{9}{|c|}{ Phenological state of the pasture } \\
\hline & \multicolumn{3}{|c|}{ 1994-1995 } & \multicolumn{3}{|c|}{ 1995-1996 } & \multicolumn{3}{|c|}{ 1996-1997 } \\
\hline & $\mathbf{V}$ & $\mathbf{R}$ & D & $\mathbf{V}$ & $\mathbf{R}$ & D & $\mathbf{V}$ & $\mathbf{R}$ & D \\
\hline & \multicolumn{9}{|c|}{$\%$} \\
\hline Bromus hordeaceus & 0.9 & 1.4 & 0.2 & 1.5 & 2.0 & 0.5 & 0.3 & 0.3 & 0.4 \\
\hline Lolium rigidum & 9.2 & 5.4 & 0.4 & 7.2 & 6.9 & 1.1 & 5.6 & 3.2 & 2.0 \\
\hline Hordeum berteroanum & 9.9 & 6.6 & 0.1 & 8.9 & 3.1 & 0.2 & 4.8 & 6.0 & 0.1 \\
\hline Vulpia bromoides & 20.7 & 7.5 & 0.1 & 21.7 & 15.4 & 0.4 & 9.3 & 7.9 & 1.7 \\
\hline Subtotal & 40.7 & 20.9 & 0.8 & 39.3 & 27.4 & 2.2 & 20.0 & 17.4 & 4.2 \\
\hline Nasella manicata & 14.9 & 3.3 & 3.1 & 9.7 & 5.2 & 5.0 & 9.2 & 2.4 & 4.2 \\
\hline Piptochaetium stipoides & 21.9 & 2.8 & 1.2 & 23.7 & 8.6 & 1.9 & 18.8 & 1.2 & 2.3 \\
\hline Subtotal & 36.8 & 6.1 & 4.3 & 33.4 & 13.8 & 6.9 & 28.0 & 3.6 & 6.5 \\
\hline Hypochaeris glabra & 8.1 & 23.9 & 0.9 & 0.3 & 8.2 & 1.9 & 0.2 & 13.7 & 0.5 \\
\hline Medicago polymorpha & 0.0 & 1.4 & 2.0 & 0.0 & 1.5 & 7.2 & 0.0 & 1.5 & 0.4 \\
\hline Subtotal & 8.1 & 25.3 & 2.9 & 0.3 & 9.7 & 9.1 & 0.2 & 15.2 & 0.9 \\
\hline Acacia caven & 9.3 & 26.0 & 69.0 & 10.2 & 18.7 & 63.9 & 18.4 & 42.6 & 48.0 \\
\hline Rubus ulmifolius & 4.4 & 21.6 & 23.0 & 16.6 & 30.3 & 17.7 & 33.1 & 21.3 & 40.5 \\
\hline Subtotal & 13.7 & 47.6 & 92.0 & 26.8 & 49.0 & 81.6 & 51.5 & 63.9 & 88.5 \\
\hline
\end{tabular}

$\mathrm{V}$ : vegetative; R: reproductive; D: dry. 
seasons. In the first year of the study, the contribution presented significant differences $(\mathrm{P} \leq 0.05)$ between the vegetative, reproductive and dry period, its contribution being $8.9,25.3$ and $2.9 \%$, respectively. In the second year, the vegetative period $(0.3 \%)$ was significantly lower $(\mathrm{P} \leq 0.05)$ than the reproductive $(9.7 \%)$ and dry periods $(9.1 \%)$. In the third year the contribution in the reproductive period was $15.2 \%$, which was significantly greater $(\mathrm{P} \leq 0.05)$ than in the dry $(0.9 \%)$ and vegetative periods $(0.2 \%)$.

The participation of woody species in the diet was highest during the reproducitve and dry periods, which indicated that the alpacas have markedly browsing habits. Within this group $A$. caven and R. ulmifolius (Table 2) are notable. Of these, A. caven had similar behavior in the three seasons studied, tending to increase its participation in the diet as the pasture enters the reproductive stage and dries, showing significant differences among the phenological periods $(\mathrm{P} \leq 0.05)$. R. ulmifolius behaved erratically, with no stable pattern of consumption.

\section{Relative diversity index (E)}

The E index calculated for the pasture had a relatively stable behavior, with a mean value for the three seasons of evaluation of $0.71(71 \%)$, with small variations that were repeated year after year, reaching the lowest points in autumn and the highest during the active growth months of the pasture (Figure 3). This indicates a relatively stable and balanced composition of species in the pasture in their respective proportions over time, which could be explained, in part, by the high number of vegetal species present in the herbaceous strata, which exceeded 49 species in this study. Nevertheless, despite this abundant supply of species, only a set of them bring together the properties to be selected by the animals. This is reflected in the $\mathrm{E}$ index of the diet, which fluctuates much more markedly, reaching the highest points in winter and the beginning of spring, during the period of active growth of the pasture and obtaining the lowest in the summer months. During the growth period of the pasture, the diet is more balanced in terms of its composition, to the contrary of what happens in the dry season, when the diet presents a lower E index. This is attributed to a lower number of species selected during this period, and as well, a greater imbalance in its proportions in the diet. Because of this, it is possible to affirm that the diet botanical composition is not necessarily a direct function of the pasture botanical composition, and to confirm that the nutritive value, reflected through the phonological state of the species of the pasture and its respective availability, are determining factors.

\section{Ivlev's Electivity index (IS)}

The variations obtained in the IS for the most important herbaceous species are presented in Figure 4 , and the average of IS for the same in each phenological state of the range is presented in Table 3. The annual grasses, $V$. bromoides and $H$. berteroanum, presented a variation over time that in certain manner is repeated year after year (Figure 4a). The IS values for these species were high during the active growing period of the herbaceous pasture, but their availability and nutritional value decreased during the dry period (Figure 4a). The same was not

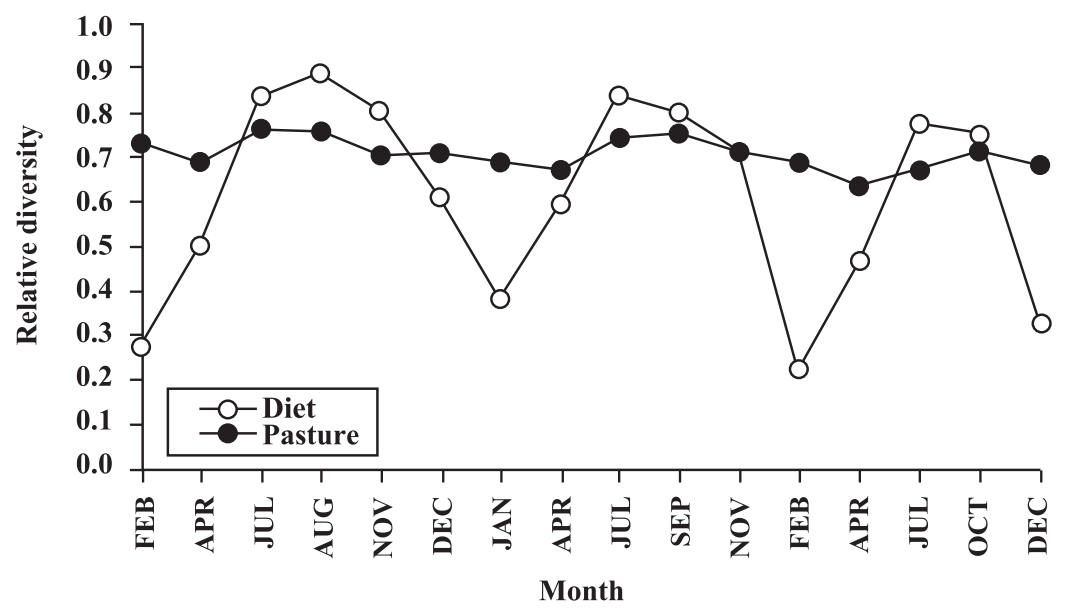

Figure 3. Shannon's Diversity Index of the diet and the pasture, expressed as relative diversity (fractional values). Hidango, Libertador General Bernardo O'Higgins Region, Chile. 
observed for L. rigidum, which maintained IS values between 0.0 and 0.5 consistently, consequently having an intermediate and relatively constant degree of selectivity over time. This could be attributed to the fact that the species maintains a high participation in the availability of the pasture, and probably its nutritional value, especially during the dry period, is higher and less variable in comparison to the other annual grasses of similar growing habits. A completely different situation was quantified for the species $B$. hordeaceus, whose IS maintained values between 1.0 and -0.5 , which indicates that it was rejected in all phenological states.

In the case of perennial grasses (Figure 4b), $N$. manicata tends to be rejected, especially during the spring and summer, and experienced a recovery at the beginning of the growing season, which coincides with the regrowth of the species. A different behavior was presented by $P$. stipoides, whose IS was high (0.98$1.0)$ and practically constant throughout the year. This would indicate that although this species contributes a very low proportion to the availability of the DM of the pasture, it is sought and consumed by the animal.

Among the herbaceous dicots (Figure 4c), H. glabra was selected in the reproductive and dry periods and rejected during the vegetative period, probably because of its low nutritional value in comparison to other species that grow actively in that period. In the majority of the measurements made of both the pasture and the diet, it was not possible to detect $M$. polymorpha, which made it impossible to quantify its IS. Nevertheless, in some measurements its presence was only detected in the diet, especially during the dry period of the pasture, which would indicate that during this phenological state it is selected by the animals.

The species that are not selected by the animals are favored in that they can complete their development cycle and perpetuate themselves over time. The more selected, by being sought and consumed by herbivores, is affected in its capacity for perpetuation, and under (a) Annual grasses

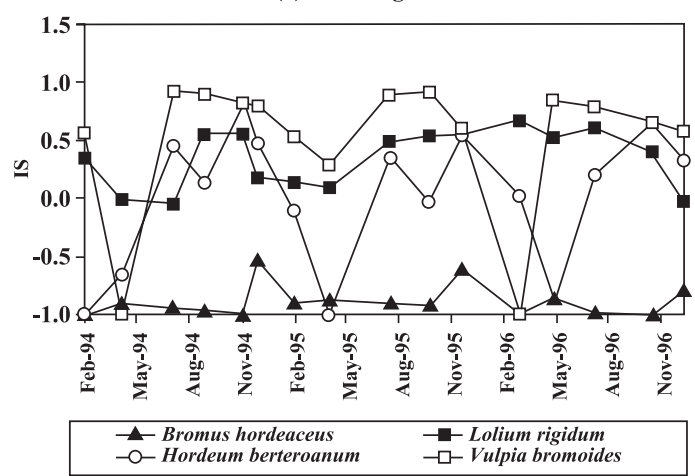

(b) Perennial grasses

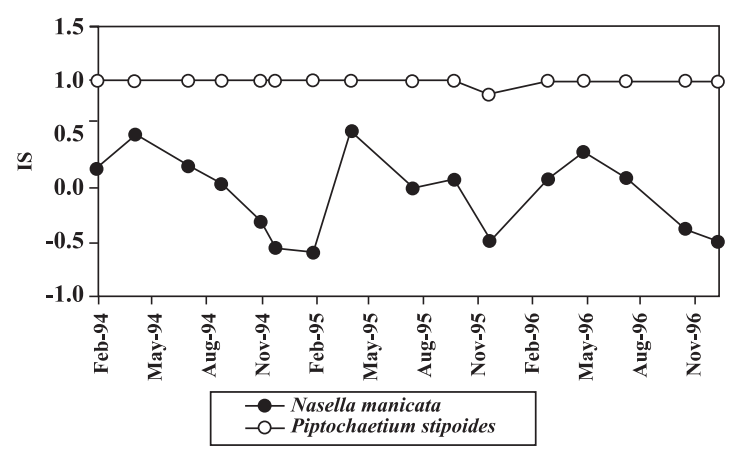

(c) Herbaceous dicots

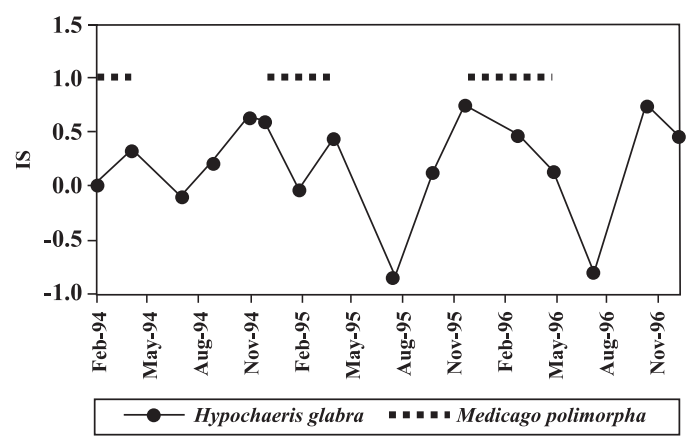

Figure 4. Ivlev's Electivity Index (IS) of different herbaceous species groups in all evaluated dates. (a) Annual grasses; (b) Perennial grasses; and (c) Herbaceous dicots. Hidango, Libertador General Bernardo O'Higgins Region, Chile. 
Table 3. Ivlev's Electivity Index (IS) calculated for the most important species of the alpaca's diet. Average for three phenological stages.

\begin{tabular}{lccc}
\hline \multirow{2}{*}{ Plant species } & \multicolumn{3}{c}{ Phenological state of the pasture } \\
\cline { 2 - 4 } & Vegetative & Reproductive & Dry \\
\hline Vulpia bromoides & 0.86 & 0.72 & 0.03 \\
Hordeum berteroanum & 0.28 & 0.46 & -0.59 \\
Bromus hordeaceus & -0.94 & -0.80 & -0.92 \\
Lolium rigidum & 0.39 & 0.36 & 0.28 \\
Piptochaetium stipoides & 1.00 & 0.98 & 1.00 \\
Nasella manicata & 0.08 & -0.38 & 0.15 \\
Hypochaeris glabra & -0.40 & 0.54 & 0.22 \\
Medicago polymorpha & $\left({ }^{1}\right)$ & $\left({ }^{1}\right)$ & 1.00 \\
\hline
\end{tabular}

(1) Indicates that at some date of each period there were no data of presence in the diet or in the pasture.

overgrazing conditions or of short resting periods, its participation in the pasture can gradually be reduced, which as a consequence brings a deterioration in the pasture condition. These data confirm that in order to classify the pasture's species in relation to its IS, the availability of the species in the pasture and the preference of the animal for the same should be considered.

\section{CONCLUSIONS}

During the vegetative period of the pasture, the alpaca's diet was composed principally of grasses. Toward the reproductive period, the consumption of woody species increased, followed by herbaceous dicots.

During the dry season of the herbaceous pasture, woody species are the main component of the alpaca's diet, reflecting the animal's browsing habit.

The relative diversity of the composition of the pasture was high and relatively stable throughout the study. This was not the case with the botanical composition of the alpaca's diet, which presented important fluctuations, observing high values in the active growth period of the pasture and very unbalanced during the dry period of the same.

Alpacas adapt their dietary habits in function of the nutritional quality and the availability of grazing species.

This study confirms that in the particular case of the alpaca, the index of selection of vegetal species varies according to the availability and preference of the animal, with the latter depending on the phenological state of the vegetal species.

\section{R E S U M E N}

Composición botánica de la dieta de alpaca (Lama pacos Linn.) en un pastizal del secano mediterráneo de la zona central de Chile. G. Castellaro G. ${ }^{1}$, F. Squella N. ${ }^{2}$, F. León C. ${ }^{3}$, y A. Raggi S. ${ }^{4}$. La reintroducción de camélidos sudamericanos domésticos (alpaca y llamas) en la zona central de Chile, hace necesario estudiar su comportamiento y adaptabilidad. En este contexto, la caracterización de la dieta es fundamental. Por ello, el presente trabajo tuvo como objetivo determinar las especies vegetales seleccionadas por las alpacas en diferentes etapas fenológicas del pastizal (vegetativo, reproductivo y seco). El estudio se realizó durante tres temporadas en un potrero de 2,5 ha ocupado por un matorral claro dominado por Acacia caven (Mol.) Mol. y especies anuales en el estrato herbáceo, las cuales fueron pastoreadas continuamente por cinco alpacas macho. En la pradera se evaluó la composición botánica y la disponibilidad de la materia seca bajo pastoreo. La composición botánica de la dieta fue estimada mediante la técnica microhistológica, utilizando muestras de fecas colectadas directamente del recto de los animales. Las especies más consumidas en el período vegetativo fueron las poáceas anuales y perennes. En el período reproductivo, las especies leñosas, poáceas anuales y dicotiledóneas herbáceas fueron los componentes más importantes de la dieta. En el período seco, la dieta estuvo constituida en un alto porcentaje por especies leñosas.

Palabras clave: alpaca, composición botánica de la dieta, pradera anual de clima mediterráneo, microhistología. 


\section{LITERATURE CITED}

Bryant, F., and R. Farfán. 1984. Dry season forage selection by alpaca (Lama pacos) in Southern Perú. J. Range Manage. 37:330-333.

Castellaro, G, M. Silva, y F. Santibáñez. 1994. Efecto de la radiación solar y la temperatura sobre las fenofases de las principales especies del pastizal mediterráneo anual. Av. Prod. Anim. 19: 65-75.

Castellaro, G., J. García-Huidobro, and P. Salinas. 1998. Alpaca liveweight variations and fiber production in Mediterranean range of Chile. J. Range Manage. 51:509-513.

Castellaro, G., F. Squella, T. Ullrich, F. León, y A. Raggi. 2006. Algunas técnicas microhistológicas utilizadas en la determinación de la composición botánica de la dieta de herbívoros. Agric. Téc. (Chile) 67:86-93

Castellaro, G., T. Ullrich,, B. Wackwitz, y A. Raggi. 2004. Composición botánica de la dieta de alpacas (Lama pacos L.) y llamas (Lama glama L.) en dos estaciones del año, en praderas altiplánicas de un sector de la provincia de Parinacota, Chile. Agric. Téc. (Chile) 64:353-364.

Cortés, A., J. Rau, E. Miranda, y J. Jiménez. 2002. Hábitos alimenticios de Lagidium viscacia y Abrocoma cinerea: roedores sintópicos en ambientes altoandinos del norte de Chile. Rev. Chil. Hist. Nat. 75:583-593.

Etienne, M., E. Caviedes, y D. Contreras. 1979. Un nuevo enfoque en la evaluación de la productividad de las praderas. Tomo II. p. 1-12. In Instituto de Investigaciones en Recursos Naturales (IREN). Seminario Metodología para el Desarrollo de Zonas en Desertificación, La Serena. 8 de mayo de 1978. IREN, CORFO, Santiago Chile.

George, N., G. Nader, N. Mc Dougald, M. Connor, and B. Forst. 2001. Annual rangeland forage quality. Rangeland Management Series. Publication 8022. 13 p. University of California, California Rangelands Research and Information Center, Davis, California, USA.

Holechek, J.L., R.D. Pieper, and C.H. Herbel. 2001. Range management, principles and practices. $4^{\text {th }}$ ed. $587 \mathrm{p}$. Prentice Hall, New Jersey, USA.

Krebs, C.J. 1989. Ecological methodology. 654 p. Harper Collins Publisher, New York, USA.

Johnston, M., A. Olivares, V. García de Cortázar, y X. Contreras. 1998. El banco de semillas del suelo y su respuesta a regímenes pluviométricos simulados. I. Comunidad de terófitas del mediterráneo semiárido. Av. Prod. Anim. 23:45-54.

Olivares, A., M. Johnston, y X. Contreras. 1998. Régimen pluviométrico del secano interior de la Región Metropolitana. Av. Prod. Anim. 23:35-43.

Olivares, A., M. Johnston, y C. Gutiérrez. 2006. Crecimiento y desarrollo de Bromus berteroanus Colla sometido a diferentes regímenes pluviométricos Agric. Téc. (Chile) 66:166-173.
Olivares, A., M. Johnston, y E. Salas. 2004. Distribución de la precipitación y producción de semillas de alfilerillo (Erodium moschatum (L.) L' Hér. Agric. Téc. (Chile) 64:251-263.

Ovalle, C., J. Aronson, A. Del Pozo, and J. Avendaño. 1990. The espinal: agroforestry systems of the Mediterranean type climate region of Chile. Agroforest. Syst. 10:213-239.

Ovalle, C., y F. Squella. 1996. Terrenos de pastoreo con pastizales anuales en el área de influencia climática mediterránea. $2^{\text {a }}$ ed. p. 429-466. In Ruiz, I. (ed.) Praderas para Chile. Ministerio de Agricultura, Instituto de Investigaciones Agropecuarias (INIA), Santiago, Chile.

Reiner, J., and C. Bryant. 1986. Botanical composition and nutritional quality of alpaca diets in two Andean rangeland communities. J. Range Manage. 39:424427.

Riveros, E., E. Neuman, A. Olivares, H. Manterola, y R. Ramírez. 1978. Variaciones estacionales en el contenido de caroteno y proteína de la pradera natural y del forraje consumido por ovinos en ecosistemas semiáridos. Av. Prod. Anim. 3:23-30.

San Martín, F., and F. Bryant. 1989. Nutrition of domesticated South American llamas and alpacas. Small Ruminant Res. 2:191-216.

Santibáñez, F., y J. Uribe. 1990. Atlas agroclimático de Chile. Regiones VI, VII, VIII y IX. 97 p. Ministerio de Agricultura, CORFO, Universidad de Chile, Facultad de Ciencias Agrarias y Forestales, Santiago, Chile.

Soil Survey Staff. 1992. Keys to soil taxonomy. $5^{\text {a }}$ ed. Technical Monograph $\mathrm{N}^{\circ} 19.541$ p. United States Department of Agriculture-Soil Conservation Service. Pocahontas Press, Blacksburg, Virginia, USA.

Soto, P., y M. Silva. 1984. Consumo de forraje de ovinos que pastorean una pradera mediterránea anual. I. Características del forraje y las dietas seleccionadas en diferentes momentos de utilización. Av. Prod. Anim. 9:51-62.

Spark, D., and J. Malechek. 1968. Estimating percentage dry weight in diets using a microscopic technique. J. Range Manage. 21:264-265.

Steel, R.G.D., y J.H. Torrie. 1988. Bioestadística. Principios y procedimientos. $622 \mathrm{p}$. McGraw-Hill, New York, USA.

Stuth, J.W. 1991. Foraging behavior. Chap. 3. p. 65-83. In Heitschmidt, R., and J. Stuth (eds.) Grazing management. An ecological perspective. Timber Press, Portland, Oregon, USA. 